\title{
INTERGRATING THE C.O.S.T.A. RESEARCH FRAMEWORK IN TEACHING OF THEMATIC ANALYSIS FOR POSTGRADUATE STUDENTS
}

\author{
King Costa (Ph.D) \\ Global Centre for Academic Research. \\ costak@researchglobal.net
}

\begin{abstract}
The C.O.S.T.A. Research Framework is a tool that was developed to assist students and novice researchers to navigate postgraduate studies with clarity and understanding. The emphasis of the method is on a five step approach comprising of (1) Concepts in research that are foundational to research language; (2) Objective of research which is being undertaken - likened to development of protocol or proposal; (3) Situation, emphasizing pre-comprehension of the current debate, likened to literature review; (4) Tact, which deals with methodological approaches to formulation of conclusions; (5) Assessment of output - ability to make judgments on trajectory followed and study results.

This current study focused on the use of thematic analysis by students and novice researchers in completion of their research reports and scientific writings, which essentially forms part of Stage 4 of the C.O.S.T.A Framework. The author used a systematic mapping review to select units of analysis for the sole purpose of demonstrating gaps and inconsistencies on the application of the concept of thematic analysis. In most research reports, students demonstrate clear articulation of methods in coding and themes generation, however, evidence of these codes and how themes were generated was not reflected on most of reports reviewed. This situation seems to be a prevalent in most research reports, which detailed explication of interpretation of participant's comments during interviews taking the prominent feature of presentation of results/findings section.

It is for this reason that the C.O.S.T.A. Research Framework (Costak, 2019) is proposed as one of the methods for teaching students about different methods of qualitative data analysis in general and thematic analysis in particular.
\end{abstract}

Key Words: COSTA Framework, Thematic Analysis, Teaching, Teaching 


\section{INTRODUCTION}

The lack of focus on systematic approach to rigor determination in qualitative research presents a philosophical quagmire and degenerative challenges to the discipline (Maguire \& Delahunt, 2017). It is required that transparency relating to the process of analysis be demonstrated right at the surface of the discourse. It is crucial for researchers to understand that, before even determination of the method of analysis is considered, the understanding that qualitative research is a method appropriate for generating knowledge grounded in human behavior and experience, as postulated by (Sandelowski, 2004). Explicating that which is researched in this paradigm dictates that human experiences are best described and interpreted by human. The notion of human interpretation of experiences of others suggests that the researcher automatically plays a pivotal role as a key research instrument (Bahrami, Soleimani, Yaghoobzadeh \& Ranjbar, 2016). As a research instrument, the researcher, in his/her trajectory to answering the research question and describing a particular phenomenon, is tasked with making subjective judgments about data collection, data analysis, coding, themeing and contextualization of data (Starks \& Trinidad, 2007). Data analysis is regarded as the most difficult phase in qualitative research and also a key stage in demonstrating achievement of what the research was about, after all (Nowell, Norris, White \& Moules, 2017; Thorne, 2000).

Literature has indicated that there are many methods of analyzing textual data, illustrated by O'Gorman and Maclntosh (2015) as:

- Template analysis

- Thematic Analysis

- Discourse Analysis

- Hermeneutics

- Grounded Theory

In this study, the focus is on student's and researcher's use of thematic analysis to formulate study conclusions. It is imperative to describe procedures and processes used by researchers when making judgments related to data reduction (Dey, 1993) in a manner that other scientists and researchers may be able to replicate (Braun \& Clarke, 2006; Malterud, 2001; Boyatzis, 1998). The researcher has noted that most postgraduate students, and in some cases, established researchers, fall short of through explication of the methods applied to every stage of the analysis, and rationale thereor (Tuckett, 2005 ). For this article, the author postulated 
some ideas into demonstration of the proccess of analysys (Costa, 2019) that seeks to achieve a well articulated methodology for rigor demonstration and replicability:

- The manner in which intruments were prepared,

- Procedures of analysys

- Presentation of findings

- Conclusions drawn from findings

It is in that regard that the COSTA QDA is hereby presented. As one of many methods within the Framework Analysis tradition (Dey, 1993), the COSTA QDA is part of the wider research pedagogy developed for assisting both students and researchers in structural frameworks for research developments. The section below demonstrates how the method was developed.

\section{METHODS}

The plight of many postgraduate students who enrol at institutions of higher learning for either $M$ or D qualifations was explicated by the researcher in his earlier works (Costa,2018). A close examination of the phenomenon indicated many challenges well researched by many scholars (Cekiso, Tshotsho, Masha \& Saziwa,2019). Of the three challenge categorised in Costa (2019), the challenge related to research capacity is the one seen as a major hurdle that students and supervisors have to navigate through. According to Mdyogolo (2012) there are three main hindrances within postgraduate research in South Africa, and these refer to:

- Supervisors who are specialists in their respective fields, but are not well versed and empowered in relation to diverse research pathways.

- Scenarios where most students at the postgraduate level have no research skills and proficiency in research language.

- An instance where there is a conflict between research coordinating unit of a university and the supervisor.

In order to determine the extent to which this problem persists in higher education institutions, the researcher used a Qualitative Mapping Review method to uncover underlying issues related to subject matter. This is a type of a body of Review Research Methods that fall within the qualitative research tradition (Grant \& Booth, 2009). Mapping Reviews were developed by the Institute of Education's Evidence for Policy and Practice Information and Co-ordinating Centre (EPPI-Centre, 2006). The development of this method was specifically for mapping out current 
and thematise existing literature, identify gaps and make recommendations for areas that needed further research (Grant \& Booth, 2009).

The steady growth and popularity being gained by this method have been recognised as useful in terms of production of better mechanism to provide sound and robust evidence-based research on published primary research (Bettany-Saltikov, 2012). This body of methods of inquiry was also stated as one of the suitable methods for postgraduare research in South Africa (Academy of Science of South Africa, 2010). The perceived strength of this methodology is highligted in its ability to enhance contextualisation of indepth analysis of literature, appraisal of current literature, identification of gaps in practice and recommendations for remedials or implementations for policy makers and researchers.

Documents/Article selection for analysis used purpossive sampling strategy (Grant \& Booth, 2009). Boolean logic (Massachusetts Institute of Technology, 2020) using operators "AND" "OR" was employed to direct document search on the following databases:

- WIReDSpace, available at: http://wiredspace.wits.ac.za/

- UPSpace Institutional Repository, available at: https://repository.up.ac.za/handle/2263/51280

- Google Scholar

- Publish or Perish

Three main key search terms were used, thus:

- "Qualitative Research Thesis"

- "novice resears" AND "thematic analysis"

- "Challenges in thematic data analysis"

Most of documents that formed part of the analysis were 17 pieces of grey literature (Adams, et al., 2016) made up of postgraduate thesis reports that purported to have used thematic analysis in obtaining conclusions. These were also followed by review of 12 articles which alluded to problems associated with the concept of thematic analysis. 
Table 1 : Thesis Reports included in the sample

\begin{tabular}{|c|c|c|c|c|c|c|}
\hline \# & Title & $\begin{array}{l}\text { Type of } \\
\text { publication }\end{array}$ & Author & $\begin{array}{l}\text { Explication of } \\
\text { analysis process }\end{array}$ & $\begin{array}{l}\text { General } \\
\text { comments }\end{array}$ & $\begin{array}{l}\text { Search } \\
\text { Terms }\end{array}$ \\
\hline 1 & $\begin{array}{l}\text { Perceived Influence } \\
\text { of Inequality on the } \\
\text { Career Development } \\
\text { of Emerging Adults } \\
\text { In South Africa }\end{array}$ & Thesis & $\begin{array}{l}\text { (Smith.A.F., } \\
\text { 2018) }\end{array}$ & $\begin{array}{l}\text { As much as } \\
\text { explication is clearly } \\
\text { articulated, actual } \\
\text { codes and themes } \\
\text { generated and how } \\
\text { that was done is } \\
\text { misssing. }\end{array}$ & $\begin{array}{l}\text { The only } \\
\text { available } \\
\text { information is } \\
\text { invivo quotations } \\
\text { of participants } \\
\text { and researcher's } \\
\text { interpretation of } \\
\text { their meaning. }\end{array}$ & $\begin{array}{l}\text { "Qualitative } \\
\text { Research } \\
\text { Thesis" }\end{array}$ \\
\hline 2 & $\begin{array}{l}\text { Professional Black } \\
\text { South African } \\
\text { Women: } \\
\text { Body Image, Cultural } \\
\text { Expectations } \\
\text { and the Workplace }\end{array}$ & Thesis & $\begin{array}{l}\text { (Papakyriakou, } \\
\text { 2014) }\end{array}$ & $\begin{array}{l}\text { Using Thematic } \\
\text { Networks, a clear } \\
\text { process was } \\
\text { attempted by the } \\
\text { researcher, and } \\
\text { codes generated } \\
\text { together with their } \\
\text { relationships to } \\
\text { themes were } \\
\text { graphically } \\
\text { demonstrated. }\end{array}$ & $\begin{array}{l}\text { Thematic } \\
\text { Networks } \\
\text { provided a } \\
\text { means of } \\
\text { demonstrating } \\
\text { code processes } \\
\text { and themes. }\end{array}$ & $\begin{array}{l}\text { "Qualitative } \\
\text { Research } \\
\text { Thesis" }\end{array}$ \\
\hline 3 & The Development of & Dissertation & (Sethuntsha, & Explication is & & "Qualitative \\
\hline
\end{tabular}




\begin{tabular}{|c|c|c|c|c|c|c|}
\hline & $\begin{array}{l}\text { a Therapeutic } \\
\text { Approach for the } \\
\text { Treatment of } \\
\text { Individuals with } \\
\text { Prader-Willi } \\
\text { Syndrome and their } \\
\text { Primary Caregivers }\end{array}$ & & 2017) & $\begin{array}{l}\text { articulated but there } \\
\text { was no evidence of } \\
\text { codes in the } \\
\text { document corpus. } \\
\text { Invivo quotes from } \\
\text { particpants are } \\
\text { interpreted in detail. }\end{array}$ & & $\begin{array}{l}\text { Research } \\
\text { Thesis" }\end{array}$ \\
\hline 4 & $\begin{array}{l}\text { Returning to work: } \\
\text { exploring the lived } \\
\text { experience of the } \\
\text { cancer survivor }\end{array}$ & Thesis & (Clur, 2015) & $\begin{array}{l}\text { Although the } \\
\text { researcher indicates } \\
\text { that the transcripts } \\
\text { were searched for } \\
\text { codes, the study does } \\
\text { not demonstrate how } \\
\text { those codes were } \\
\text { generated, how many } \\
\text { they were, how they } \\
\text { were sorted to } \\
\text { generate final themes } \\
\text { discussed in the } \\
\text { study. }\end{array}$ & $\begin{array}{l}\text { Invivo quotes } \\
\text { from participants } \\
\text { were the only } \\
\text { evidence of } \\
\text { analysis } \\
\text { provided, } \\
\text { followed by } \\
\text { research's } \\
\text { interpretation of } \\
\text { these } \\
\text { expressions. }\end{array}$ & $\begin{array}{l}\text { "Qualitative } \\
\text { Research } \\
\text { Thesis" }\end{array}$ \\
\hline 5 & $\begin{array}{l}\text { The impact of group } \\
\text { coaching on } \\
\text { leadership } \\
\text { effectiveness for }\end{array}$ & Thesis & (Reid, 2012) & $\begin{array}{l}\text { Explication is clearly } \\
\text { articulated but exact } \\
\text { codes and their } \\
\text { numbers are not }\end{array}$ & $\begin{array}{l}\text { Invivo quotations } \\
\text { take prominence } \\
\text { of the } \\
\text { interpretations. }\end{array}$ & $\begin{array}{l}\text { "Qualitative } \\
\text { Research } \\
\text { Thesis" }\end{array}$ \\
\hline
\end{tabular}




\begin{tabular}{|c|c|c|c|c|c|c|}
\hline & $\begin{array}{l}\text { South African } \\
\text { women managers }\end{array}$ & & & $\begin{array}{l}\text { reflected, except that } \\
\text { subthemes are } \\
\text { indicated and their } \\
\text { connection to main } \\
\text { study themes. }\end{array}$ & & \\
\hline 6 & $\begin{array}{l}\text { Exploring } \\
\text { experiences of } \\
\text { adolescents living } \\
\text { with a depressed } \\
\text { parent }\end{array}$ & Thesis & (Makuwa, 2014) & $\begin{array}{l}\text { Knowledge of } \\
\text { processes is inherent } \\
\text { in explications of } \\
\text { approach and } \\
\text { theoretical basis, yet } \\
\text { no evidence of these } \\
\text { codes was present in } \\
\text { the study. }\end{array}$ & $\begin{array}{l}\text { Invivo quotations } \\
\text { take prominence } \\
\text { of the } \\
\text { interpretations. }\end{array}$ & $\begin{array}{l}\text { "Qualitative } \\
\text { Research } \\
\text { Thesis" }\end{array}$ \\
\hline 7 & $\begin{array}{l}\text { A Thematic Analysis } \\
\text { of Substance- } \\
\text { Abusing Mothers' } \\
\text { and Their Children's } \\
\text { Discussions during } \\
\text { Family Therapy }\end{array}$ & Thesis & $\begin{array}{l}\text { (Brakenhoff, } \\
\text { 2012) }\end{array}$ & $\begin{array}{l}\text { As much as the study } \\
\text { title indicates thematic } \\
\text { analysis, methods } \\
\text { followed to produce } \\
\text { final conclusions are } \\
\text { not clearly } \\
\text { demonstrated. }\end{array}$ & & $\begin{array}{l}\text { "Qualitative } \\
\text { Research } \\
\text { Thesis" }\end{array}$ \\
\hline 8 & $\begin{array}{l}\text { How has surrender } \\
\text { been written about in } \\
\text { psychoanalytic } \\
\text { psychotherapy }\end{array}$ & Thesis & $\begin{array}{l}\text { (Southwel, } \\
\text { 2013) }\end{array}$ & $\begin{array}{l}\text { The study explained, } \\
\text { reflected and } \\
\text { captured codes } \\
\text { trajectory well, in a }\end{array}$ & & $\begin{array}{l}\text { "Qualitative } \\
\text { Research } \\
\text { Thesis" }\end{array}$ \\
\hline
\end{tabular}




\begin{tabular}{|c|c|c|c|c|c|c|}
\hline & & & & $\begin{array}{l}\text { manner that can be } \\
\text { replicable and } \\
\text { followed by other } \\
\text { scientific researchers. } \\
\text { Codes are clearly } \\
\text { enumerated and well } \\
\text { assigned. }\end{array}$ & & \\
\hline 9 & $\begin{array}{l}\text { A qualitative action } \\
\text { research study } \\
\text { introducing a } \\
\text { metacognitive } \\
\text { framework for } \\
\text { teaching preparation } \\
\text { and analysis of its } \\
\text { efficacy }\end{array}$ & Thesis & $\begin{array}{l}\text { (Sylvester, } \\
\text { 2016) }\end{array}$ & $\begin{array}{l}\text { The study explained } \\
\text { procedures for data } \\
\text { analysis including } \\
\text { creation of codes. }\end{array}$ & $\begin{array}{l}\text { No evidence of } \\
\text { codes found in } \\
\text { the study. A } \\
\text { detailed } \\
\text { reflection of } \\
\text { participant's } \\
\text { reactions to } \\
\text { interview } \\
\text { questions are } \\
\text { presented and } \\
\text { interpreted. }\end{array}$ & $\begin{array}{l}\text { "Qualitative } \\
\text { Research } \\
\text { Thesis" }\end{array}$ \\
\hline 10 & $\begin{array}{l}\text { Challenges and } \\
\text { opportunities } \\
\text { experienced by } \\
\text { people with a } \\
\text { physical disability in } \\
\text { Alexandra, Gauteng }\end{array}$ & Thesis & $\begin{array}{l}\text { (Mthembu, } \\
\text { 2017) }\end{array}$ & $\begin{array}{l}\text { No clear procedures } \\
\text { mentioned. The } \\
\text { presentation of } \\
\text { findings focusses on } \\
\text { themes but there is no } \\
\text { information of how }\end{array}$ & $\begin{array}{l}\text { There is no } \\
\text { evidence of } \\
\text { coding in the } \\
\text { study. }\end{array}$ & $\begin{array}{l}\text { "Qualitative } \\
\text { Research } \\
\text { Thesis" }\end{array}$ \\
\hline
\end{tabular}




\begin{tabular}{|c|c|c|c|c|c|c|}
\hline & & & & $\begin{array}{l}\text { these themes were } \\
\text { generated from data. }\end{array}$ & & \\
\hline 11 & $\begin{array}{l}\text { The Lived } \\
\text { Experience: A } \\
\text { qualitative study of } \\
\text { mentally ill women } \\
\text { who commit filicide. }\end{array}$ & Thesis & (Moodley, 2019) & $\begin{array}{l}\text { Although procedures } \\
\text { are mentioned under } \\
\text { the Research } \\
\text { Methods Chapter, the } \\
\text { presentation of results } \\
\text { makes no mention of } \\
\text { how themes were } \\
\text { generated from data } \\
\text { itself. }\end{array}$ & $\begin{array}{l}\text { A detailed } \\
\text { account of } \\
\text { experiences as } \\
\text { emanating from } \\
\text { interview } \\
\text { questions is } \\
\text { provided. } \\
\text { However, this } \\
\text { data is not } \\
\text { codified. }\end{array}$ & $\begin{array}{l}\text { "Qualitative } \\
\text { Research } \\
\text { Thesis" }\end{array}$ \\
\hline 12 & $\begin{array}{l}\text { Living with cancer of } \\
\text { the head and neck: a } \\
\text { qualitative inquiry } \\
\text { into the experiences } \\
\text { of patients treated at } \\
\text { an academic hospital } \\
\text { in Gauteng }\end{array}$ & Thesis & (Bingo, 2018) & $\begin{array}{l}\text { Methods are clearly } \\
\text { explicated, } \\
\text { however,the results } \\
\text { section does not } \\
\text { reflect evidence of the } \\
\text { "ideas" that were } \\
\text { broken down to } \\
\text { generate themes. }\end{array}$ & & $\begin{array}{l}\text { "Qualitative } \\
\text { Research } \\
\text { Thesis" }\end{array}$ \\
\hline 13 & $\begin{array}{l}\text { Leadership } \\
\text { development for } \\
\text { women at the } \\
\text { department of home }\end{array}$ & Thesis & (Mlokothi, 2017) & $\begin{array}{l}\text { Methods are clearly } \\
\text { explicated but there is } \\
\text { no evidence of the } \\
\text { coding process and }\end{array}$ & & $\begin{array}{l}\text { "Qualitative } \\
\text { Research } \\
\text { Thesis" }\end{array}$ \\
\hline
\end{tabular}




\begin{tabular}{|c|c|c|c|c|c|c|}
\hline & affairs & & & $\begin{array}{l}\text { how sub-themes and } \\
\text { themes were } \\
\text { generated. }\end{array}$ & & \\
\hline 14 & $\begin{array}{l}\text { Challenges and } \\
\text { Opportunities of a } \\
\text { Donor-Funded Not- } \\
\text { for-Profit } \\
\text { Organisation: a } \\
\text { SWOT Analysis of } \\
\text { Vikela Project, a } \\
\text { Business Unit of } \\
\text { Composite Health }\end{array}$ & & $\begin{array}{l}\text { (Mukuvisi, } \\
\text { 2011) }\end{array}$ & $\begin{array}{l}\text { No method of data } \\
\text { reduction mentioned } \\
\text { and codes were not } \\
\text { created for themes } \\
\text { generation. }\end{array}$ & & $\begin{array}{l}\text { "Qualitative } \\
\text { Research } \\
\text { Thesis" }\end{array}$ \\
\hline 15 & $\begin{array}{l}\text { An exploratory study } \\
\text { into the critical } \\
\text { success factors for } \\
\text { effective stakeholder } \\
\text { engagement in } \\
\text { blended finance } \\
\text { projects }\end{array}$ & Thesis & (Francis, 2019) & $\begin{array}{l}\text { Methods of coding } \\
\text { clearly explicated and } \\
\text { executed with a } \\
\text { reported result of } 171 \\
\text { codes. However, } \\
\text { there is no evidence } \\
\text { of codes as } \\
\text { transposed from data } \\
\text { documents. }\end{array}$ & $\begin{array}{l}\text { Use of coding } \\
\text { and explications } \\
\text { well articulated }\end{array}$ & $\begin{array}{l}\text { "Qualitative } \\
\text { Research } \\
\text { Thesis" }\end{array}$ \\
\hline
\end{tabular}




\begin{tabular}{|c|c|c|c|c|c|c|}
\hline 16 & $\begin{array}{l}\text { Contextual } \\
\text { intelligence } \\
\text { behaviours: } \\
\text { managers in } \\
\text { multinational } \\
\text { enteprises } \\
\text { developing emerging } \\
\text { markets }\end{array}$ & Thesis & (Felix, 2019) & $\begin{array}{l}\text { Procedures for data } \\
\text { analysis including } \\
\text { coding of data is well } \\
\text { articulated in } \\
\text { Research } \\
\text { Methodology chapter. } \\
\text { However, in } \\
\text { presentation of } \\
\text { findings, there is no } \\
\text { explication of how } \\
\text { codes were } \\
\text { developed, themes } \\
\text { generated and } \\
\text { number of codes in } \\
\text { the study. }\end{array}$ & $\begin{array}{l}\text { Invivo quotes } \\
\text { from participants } \\
\text { make a dominant } \\
\text { feature of } \\
\text { findnigs/results } \\
\text { presentations. }\end{array}$ & $\begin{array}{l}\text { "Qualitative } \\
\text { Research } \\
\text { Thesis" }\end{array}$ \\
\hline 17 & $\begin{array}{l}\text { Expecting the } \\
\text { Unexpected: How } \\
\text { Novice Researchers } \\
\text { Negotiate } \\
\text { Unexpected Ethical } \\
\text { Issues }\end{array}$ & Thesis & $\begin{array}{l}\text { (Chambers, } \\
2014 \text { ) }\end{array}$ & $\begin{array}{l}\text { This research report } \\
\text { articulates methods of } \\
\text { thematic analysis, } \\
\text { explicating how } \\
\text { themes are generated } \\
\text { from codes ad using } \\
\text { known authorities for } \\
\text { argument } \\
\text { substantiation. }\end{array}$ & & $\begin{array}{l}\text { "novice } \\
\text { resears" } \\
\text { AND } \\
\text { "thematic } \\
\text { analysis" }\end{array}$ \\
\hline
\end{tabular}




\begin{tabular}{|l|l|l|l|l|}
\hline & & $\begin{array}{l}\text { However, there is no } \\
\text { evidence of how } \\
\text { codes were created } \\
\text { and how they were } \\
\text { finally sorted to } \\
\text { produce themes. }\end{array}$ & \\
\hline
\end{tabular}




\section{FINDINGS}

This study assessed 17 thesis reports from four universities in South Africa, and one university in the United States of America. The rationale for the number of dissertations was based on two main factors, first of all, Qualitative Evidence Synthesis methods use selective techniques for drawing samples to be analysed (Grant \& Booth, 2009). The search was conducted on institutional repositories of these insitutions available on the internet, while two reports were found on Goggle Scholar. Search terms used were "Qualitative Research Thesis".

It should further be noted that the second reason was based on informational redundancy of Guba and Lincoln (1985), as substantiated later on in the information power of Malterud, Siersma and Guassora (2015). This is a concept commonly known as saturation, with its origins in Grounded Theory (Glaser \& Strauss, 1967). Although originally used for demonstration of no new data influence on theoretical categories created, the concept has far evolved from its original meaning to include a situation of "no new data", or "no new themes" or "no new codes" (Guest, Bunce \& Johnson, 2006).

Based on these views, the researcher concluded that most thesis reports would demonstrate lack of indepth coding strategies and evidence of codes in the reports, either in the document corpus or as annexures. This view is widely supported in literature on thematic analysis by leading scholars such as Boyatzis (1998) ; Braun and Clarke (2006). Articles in demonstration of the incorrect use of Thematic Analysis by authors were also searched on Publish or Perish database, using search terms, "challenges in thematic data analysis", which resulted in 100 responses. Of these, the following articles selected for evidence regarding misuse or requirements for methodical replication of thematic analysis were selected. The reason for this selection was to demonstrate to the reader that the correct use of thematic analysis is a subject being discussed over a period of two decades since the work of Braun and Clarke (2006), who have over the years emphasised the need for deeper understanding of this technique. 


\begin{tabular}{|c|c|c|c|}
\hline$\#$ & Title & Author & Search Terms \\
\hline 1 & $\begin{array}{l}\text { Doing thematic analysis: A practical, } \\
\text { step-by-step guide for learning and } \\
\text { teaching scholars }\end{array}$ & $\begin{array}{l}\text { (Maguire \& } \\
\text { Delahunt, 2017) }\end{array}$ & $\begin{array}{l}\text { "Challenges in } \\
\text { thematic data } \\
\text { analysis" }\end{array}$ \\
\hline 2 & Thematic Analysis & (Terry, et al., 2017) & $\begin{array}{l}\text { "Challenges in } \\
\text { thematic data } \\
\text { analysis" }\end{array}$ \\
\hline 3 & $\begin{array}{l}\text { Thematic Analysis: Striving to Meet the } \\
\text { Trustworthiness Criteria }\end{array}$ & $\begin{array}{l}\text { (Nowell, et al., } \\
2017)\end{array}$ & $\begin{array}{l}\text { "Challenges in } \\
\text { thematic data } \\
\text { analysis" }\end{array}$ \\
\hline 4 & $\begin{array}{l}\text { Teaching thematic analysis: Overcoming } \\
\text { challenges and developing strategies for } \\
\text { effective learning. }\end{array}$ & $\begin{array}{l}\text { (Clarke \& Braun, } \\
2013)\end{array}$ & $\begin{array}{l}\text { "Challenges in } \\
\text { thematic data } \\
\text { analysis" }\end{array}$ \\
\hline 5 & Thematic Analysis & (Clarke, et al., 2015) & $\begin{array}{l}\text { "Challenges in } \\
\text { thematic data } \\
\text { analysis" } \\
\end{array}$ \\
\hline 6 & Using thematic analysis in psychology & $\begin{array}{l}\text { (Clarke \& Braun, } \\
2006)\end{array}$ & $\begin{array}{l}\text { "Challenges in } \\
\text { thematic data } \\
\text { analysis" }\end{array}$ \\
\hline 7 & $\begin{array}{l}\text { Theme development in qualitative } \\
\text { content analysis and thematic analysis }\end{array}$ & $\begin{array}{l}\text { (Vaismoradi, et al., } \\
\text { 2016) }\end{array}$ & $\begin{array}{l}\text { "Challenges in } \\
\text { thematic data } \\
\text { analysis" }\end{array}$ \\
\hline 8 & $\begin{array}{l}\text { Thematic analysis of qualitative research } \\
\text { data: Is it as easy as it sounds? }\end{array}$ & $\begin{array}{l}\text { (Castleberry } \\
\text { Nolen, 2018) }\end{array}$ & $\begin{array}{l}\text { "Challenges in } \\
\text { thematic data } \\
\text { analysis" }\end{array}$ \\
\hline 9 & $\begin{array}{l}\text { Understanding Thematic Analysis and its } \\
\text { Pitfall }\end{array}$ & $\begin{array}{l}\text { (Javadi \& Zarea, } \\
\text { 2016) }\end{array}$ & $\begin{array}{l}\text { "novice resears" } \\
\text { AND "thematic } \\
\text { analysis" }\end{array}$ \\
\hline 10 & $\begin{array}{l}\text { The thematic analysis of interview data: } \\
\text { an approach used to examine the } \\
\text { influence of the market on curricular } \\
\text { provision in Mongolian higher education } \\
\text { institutions }\end{array}$ & (Jugder, 2016) & $\begin{array}{l}\text { "novice resears" } \\
\text { AND "thematic } \\
\text { analysis" }\end{array}$ \\
\hline 11 & $\begin{array}{l}\text { Research Methods for Business \& } \\
\text { Management }\end{array}$ & $\begin{array}{l}\text { (O’Gorman \& } \\
\text { Maclntosh, 2015) }\end{array}$ & $\begin{array}{l}\text { "novice resears" } \\
\text { AND "thematic } \\
\text { analysis" }\end{array}$ \\
\hline 12 & $\begin{array}{l}\text { Developing a teaching research culture } \\
\text { for general practice registrars in } \\
\text { Australia: a literature review }\end{array}$ & (Kljakovic, 2009) & $\begin{array}{l}\text { "novice resears" } \\
\text { AND "thematic } \\
\text { analysis" }\end{array}$ \\
\hline
\end{tabular}




\section{INTRODUCING THE C.O.S.T.A. QUALITATIVE DATA ANALYSIS METHOD}

The COSTA QDA (or CQDA) is a form of Framwork Analysis and follows on traditional methods of qualitative data analysis and further hinges strongly on the Thematic Analysis of Braun and Clark (2006). Like most TAs, the CQDA has six (6) sequential stages, each with a critical iterative process for data reduction and generation of themes (Denzin \& Lincoln, 2000; Dey, 1993). A general consensus exists among scholars that proper implementation of thematic analysis produces trustworthy and reliable insightful findings, albeit the fact that no one method is singled out for attainment of this (Clarke \& Braun, 2006). Whereas the author is aware that there are many approaches to thematic analysis (Henn, Weistein \& Foard, 2009), this method is hereby proposed as a flexible approach to demonstrate rigour in qualitative data analysis. Scolars have indicated the importance of demonstrating how the process of data "...recording, gathering, sorting, deciphering analyzing and synthesizing, dissecting and articulating" was carried out in qualitative research (Denzin \& Lincoln, 2000). The six stages of the CQDA seek to demonstrate these processes in a simple yet rigourous appraoch.

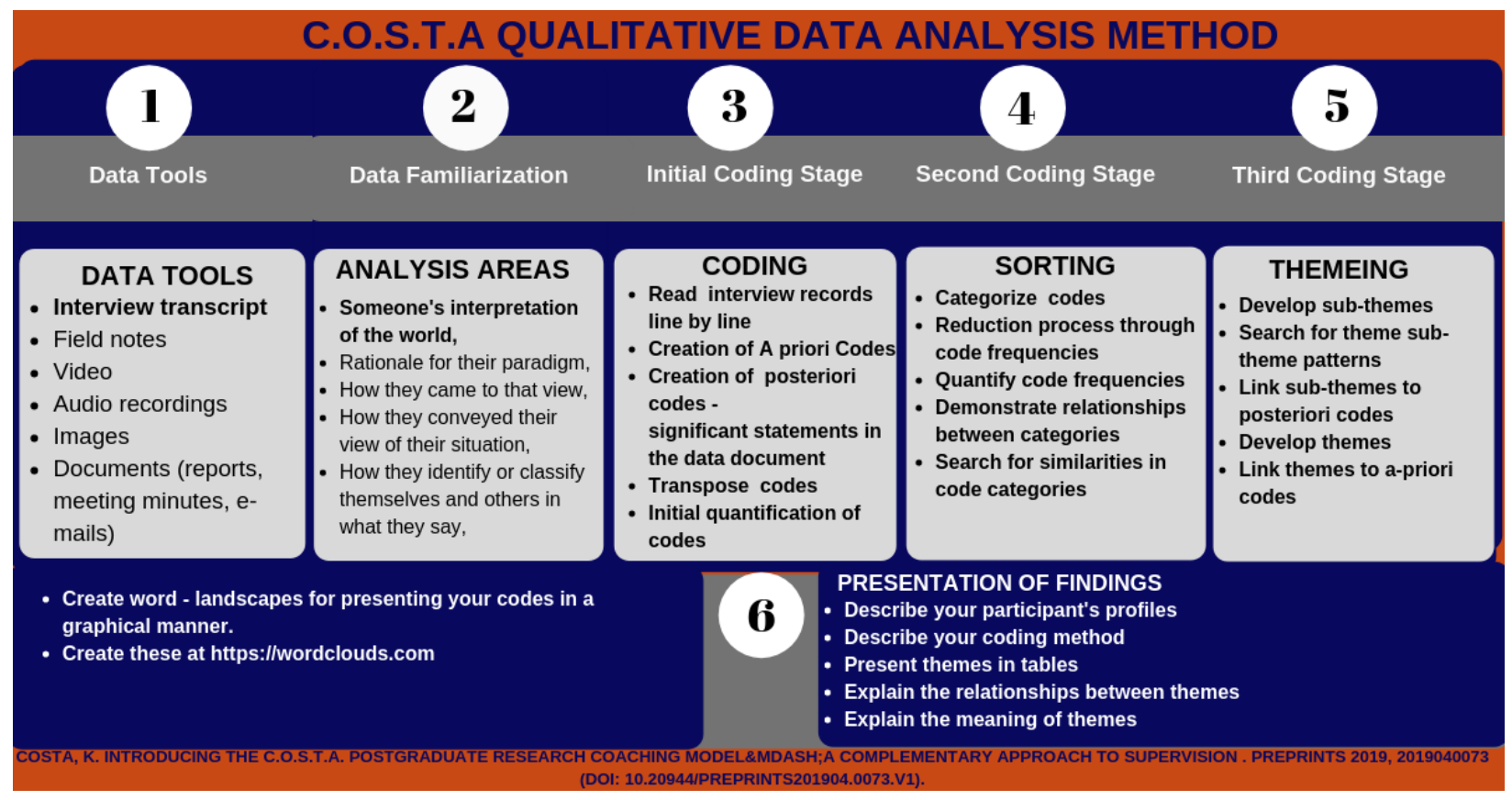

Figure 1: COSTA QDA 


\section{Data tools}

The very aspect of the nature of the researcher being an instrument has profound effects on the outcome of results. It is crucial to note that the researcher assert that the participant is also important for establishment of the strength or weakness of the investigator being an instrument (Pezalla, Pettigrew \& Miller-Day,2012). It is therefore necessary for the researcher to ensure empathy, transparency, positive regard and participant ease during the process of the interview (Mallozzi, 2009; Matteson \& Lincoln, 2009; Janesick, 2001). Data tools are critical in qualitative research, as they offer basic materials to be analyzed in order to answer the main research question and reach objectives of the inquiry. These include interview transcripts, field notes, audio/video recordings, images and documents such as reports, minutes, emails etc. Where interviews were conducted and conversations recorded, permission ought to have been sought in terms of ethical clearance from the respective institutional review boards or ethical clearance committees. Proper administration of tools at this stage is very critical. Researchers need to be encouraged to also keep records of their own reflections during the process as these are critical for establishment of the principle of confirmability (Loh, 2013). Whether the analysis is on transcripts of primary data or review of secondary research, the CQDA is flexible and applicable across different contexts of analysis (Boyatzis, 1998).

\section{Data Familiarisation}

This process is critical and fundamental establishment of the principle of "immersion" as postulated by (Thorne, 2000). Immersing self in data involves iterative reading, going back and forth in data to make sense of what it presents. Data transcription provides this opportunity for researchers. However, for big data, it could be impossible to transcribe all the data. Electronic devices are available for assisting researchers with this aspect (Costa \& Amado, 2018). In this context, big data refers to voluminous transcribed data from interviews. One interview which lasts between 45 minutes to one hour is likely to produce between 15 and 25 pages of transcribed data. If the researcher is interviewing 8 participants in a particular study, the number of transcriptions is likely to be close to 800 pages. That is why the use of software plays a pivotal role right from the beginning (Costa \& Amado, 2018). However, researchers are still encouraged to read through the data line by line and word by word to make sense of nuances and underlying messages. 
This stage familiarizes the research with issues such as participant's perspectives, paradigms and how the present themselves in relation to the phenomenon being researched in that paradigm. At this stage, researcher reflexivity kicks in, as the researcher needs to be aware of how they are impacted by the data and how such impact may affect the analytic process (Starks \& Trinidad, 2007). 


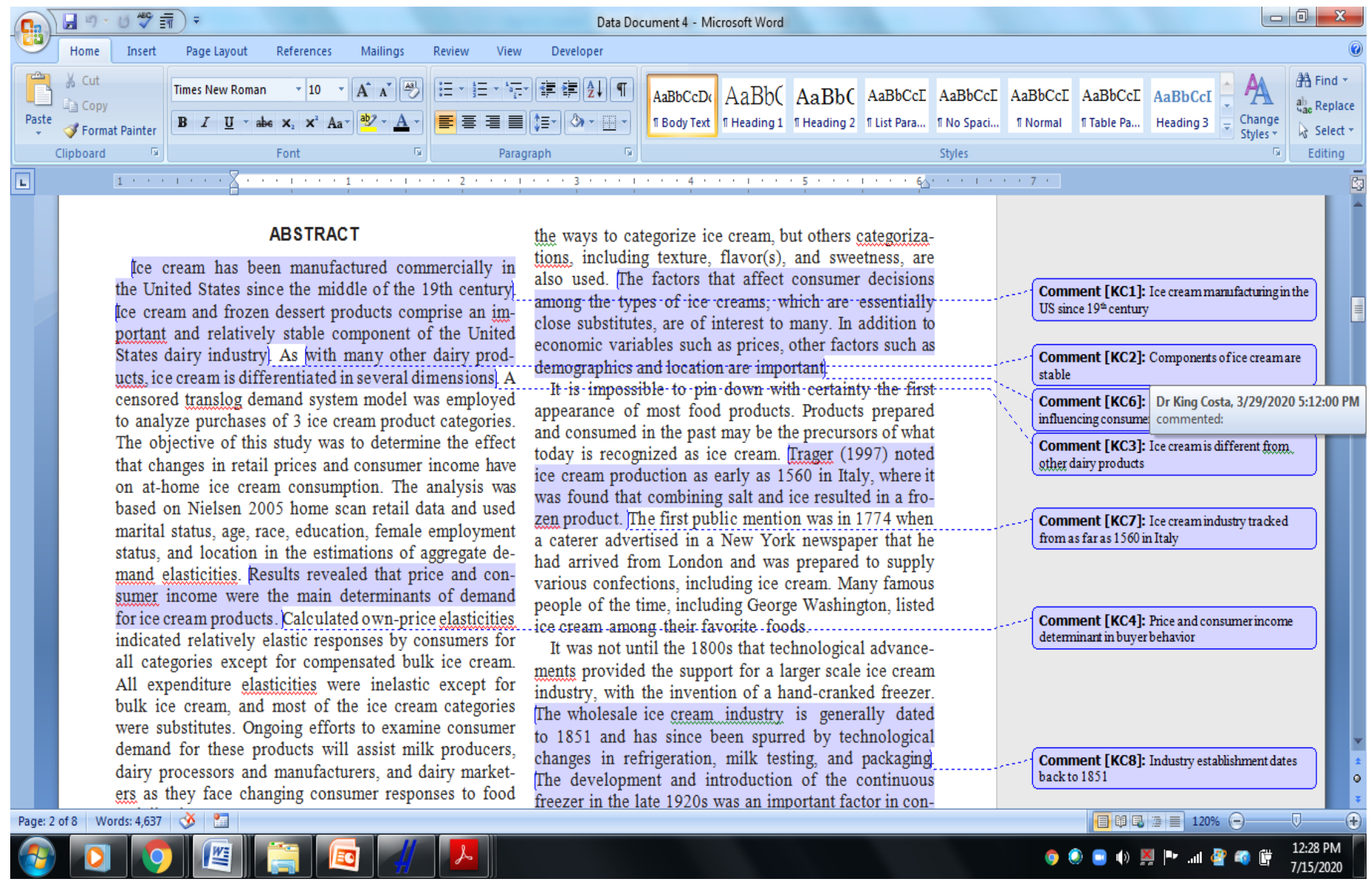

Figure 2: Coding of data documents 


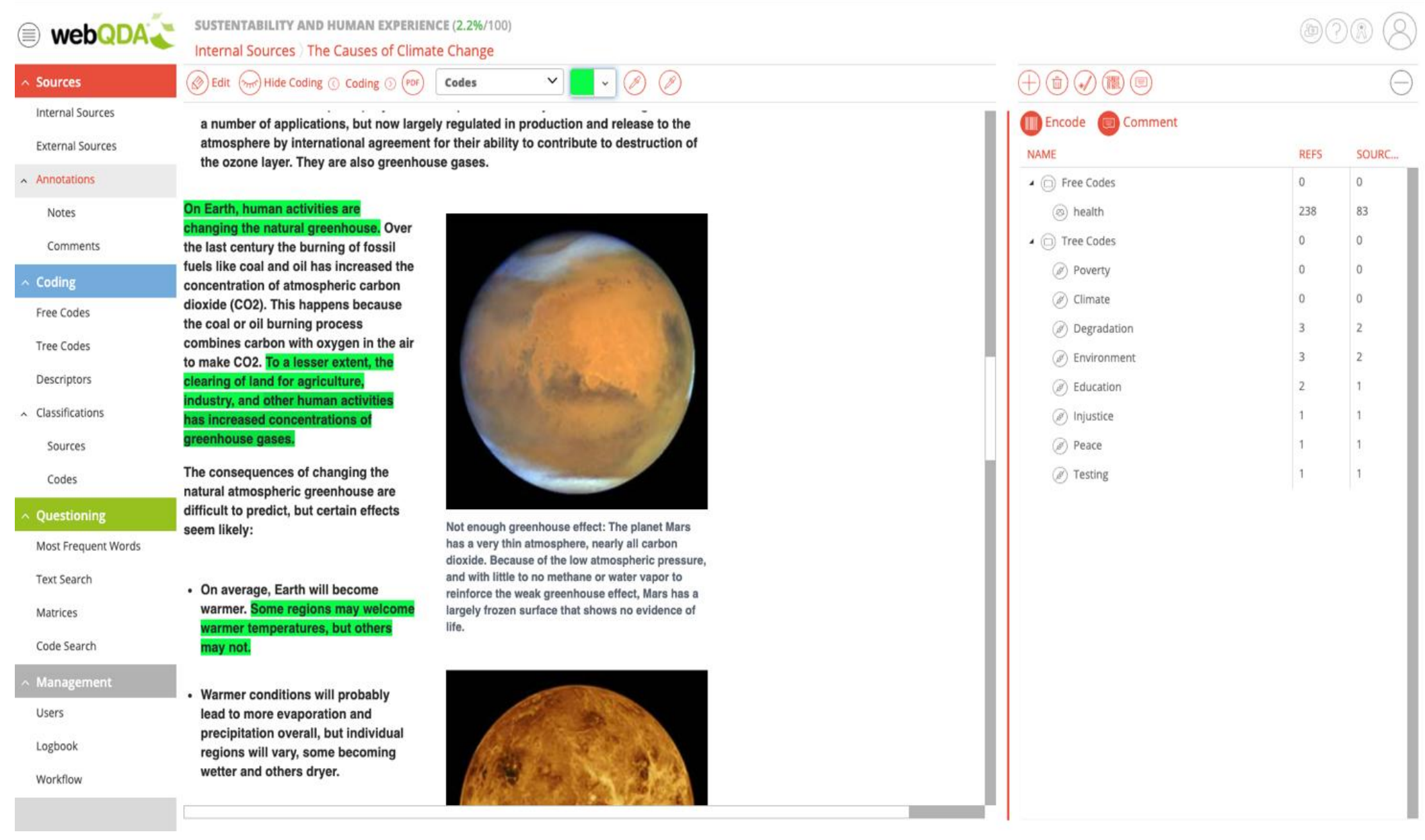

Figure 3: Data coding using webQDA 


\section{Initial Coding Stage and Second Coding stage (Axial Coding)}

A code is simply a phrase label used in qualitative research for purposes of assigning an attribute that captures the underlying essences of data and between data (Saldana, 2016). These are textual in nature and may be drawn from articles in newspapers,social media networks, images, artefacts, reports and peer reviewed (textual) materials.

This stage requires the researcher to decide on the coding strategy to be used. The CQDA recommends that the research question be closely examined and concepts used in the question be used for creation of anchor codes (also known as deductive or a priori codes). This helps to link codes from the data document to the purpose of the research itself. The actual linking occurs when the researcher reads the data document line by line and word by word following an iterative process (Hsieh \& Shannon, 2005; Braun \& Clarke, 2006).

As indicated above, manual coding presents massive difficulties for the researchers in terms of authenticating codes and ensuring that no mistakes occur. The intergration of software platform using CQDA makes this function easier while managing and storing the data safely.

Once a decision is made regarding a chosen strategy, then the coder transposes all codes from data documents to a new document where sorting, frequency determination and characterization of initial codes occurs. The coder is able to conduct two types of coding activities:

- Two-step Hierachial coding: whereby the coder links the inductive codes to anchor codes, as demonstrated in Figure 3 below. This is useful in research that links findings to theory and research questions. All concepts in the research question (topic) become anchor codes/deductive codes, allowing the researcher to link all codes emerging from data with suitable codes emanating from the research question of topic (Hsieh \& Shannon, 2005).

The example below uses extual codes used in a study entitled "The perceived effectiveness of executive coaching for leadership development in South Africa

(Mvelase, 2019). The full study may be viewed at: https://hdl.handle.net/10539/29106. 


\begin{tabular}{|c|c|c|c|c|c|c|c|}
\hline $\begin{array}{l}2 . \\
3 . \\
4 . \\
5 . \\
6 . \\
7 . \\
8 . \\
9 .\end{array}$ & $\begin{array}{l}\text { Development: government } \\
\text { contributes towards coaching } \\
\text { through SETA funding } \\
\text { programmes } \\
\text { Development - my company } \\
\text { develops leaders and managers } \\
\text { Effectiveness: Business acumen } \\
\text { and role understanding } \\
\text { Effectiveness: We prioritise } \\
\text { people development } \\
\text { Development : company offers } \\
\text { leadership development } \\
\text { Development: covers people } \\
\text { and management skills. } \\
\text { Development: emphasis on } \\
\text { mentorship } \\
\text { Perception: coaching is the best } \\
\text { approach } \\
\text { Perception: Coaching makes a } \\
\text { person understand concepts } \\
\text { much better } \\
\text { Perception: Coaching helps in } \\
\text { self discovery, } \\
\text { Perception: Coaching helps in } \\
\text { discovering challenges and } \\
\text { solutions to challenges. } \\
\text { Perception: Teaching is simply } \\
\text { spoonfeeding someone with } \\
\text { information. } \\
\text { Perception: Coaching helps one } \\
\text { to discover what they want to } \\
\text { learn. } \\
\text { Perception: coaching helps } \\
\text { individuals find their own } \\
\text { solutions to challenges. } \\
\text { Perception: Coaching is done } \\
\text { through questioning. } \\
\text { Development: Leadership } \\
\text { Development implemented. }\end{array}$ & $\begin{array}{l}17 . \\
18 . \\
19 . \\
20 . \\
21 . \\
22 . \\
23 . \\
24 . \\
25 . \\
26 . \\
32 . \\
32 . \\
28 . \\
32 .\end{array}$ & $\begin{array}{l}\text { Development :Two } \\
\text { programmes in the company } \\
\text { Development: Programme in } \\
\text { place for first line management } \\
\text { Development: Programme for } \\
\text { first line management. } \\
\text { Development: Khulisa prepares } \\
\text { people to sales management } \\
\text { position. } \\
\text { Development: Programme } \\
\text { Elevate prepares managers to } \\
\text { executive level. } \\
\text { Development: Business } \\
\text { Acumen is at Executive Level. } \\
\text { Expectations: Coaching should } \\
\text { start with gap analysis. } \\
\text { Expectations: Searching what is } \\
\text { missing. } \\
\text { Expectations: There should be a } \\
\text { missing link. } \\
\text { Perception: Underperformance } \\
\text { needs to be investigated. } \\
\text { Perception: Skills or Will } \\
\text { shortage needs to be } \\
\text { investigated. } \\
\text { Expectations: Skills Matrix to be } \\
\text { developed to close the gap. } \\
\text { Perception: Skills can be } \\
\text { learned and taught } \\
\text { Perception: Will cannot be } \\
\text { taught } \\
\text { Expectation: Coaching to make } \\
\text { people better performances. } \\
\text { Perception: Efficiency can be } \\
\text { attributed to massive skills } \\
\text { impartation. }\end{array}$ & $\begin{array}{l}34 . \\
35 . \\
36 . \\
37 . \\
38 . \\
39 . \\
40 .\end{array}$ & $\begin{array}{l}\text { Perception: Inefficient } \\
\text { companies indicate that there is } \\
\text { no skills impartation/coaching. } \\
\text { Perception: If people are } \\
\text { skilled, then they are not willing } \\
\text { to perform and that indicates } \\
\text { lack of coaching. } \\
\text { Perception: Coaching is a } \\
\text { cornerstone of business. } \\
\text { Perception: Coaching should be } \\
\text { ongoing. } \\
\text { Perception: Coaching should be } \\
\text { continuous improvement. } \\
\text { Perception: Coaching should be } \\
\text { continuous. } \\
\text { Perception: Coaching should be } \\
\text { continuous. } \\
\text { Perception: When you have } \\
\text { done better, there is always } \\
\text { room for improvement - } \\
\text { continuous improvement } \\
\text { Experience: My perceptions are } \\
\text { resulting from the coaching I } \\
\text { received. } \\
\text { Perception: Coaches need to be } \\
\text { emotionally empathetic. } \\
\text { Perception: Coaches need to } \\
\text { invest in emotional bank } \\
\text { account of individuals. } \\
\text { Perception: Lack of empathy } \\
\text { creates rejection. } \\
\text { Perception: Use of leadership } \\
\text { theories of Stephen Covey. } \\
\text { Perception - Skills not suited } \\
\text { for coaching: arrogance, } \\
\text { aggressions. } \\
\text { Perception - Skills not suited } \\
\text { for coaching: Belittling the } \\
\text { listener/coachee }\end{array}$ & $\begin{array}{l}50 . \\
51 . \\
52 . \\
53 . \\
54 . \\
55 . \\
56 . \\
57 .\end{array}$ & $\begin{array}{l}\text { Perception: Sales Managers are } \\
\text { appropriately suited for } \\
\text { coaching. } \\
\text { Perception: Floor managers } \\
\text { who deal with agents also need } \\
\text { coaching. } \\
\text { Perception: Everyone needs } \\
\text { coaching. } \\
\text { Perception: Everyone up to MD } \\
\text { needs coaching. } \\
\text { Perception: Coaching provides } \\
\text { positive outcomes } \\
\text { Perception: Coaching's aim is } \\
\text { performance improvement. } \\
\text { Perception: Performance } \\
\text { improvement } \\
\text { Perception: Coaching not only } \\
\text { on skills gaps BUT also habits. } \\
\text { Perception: Coaching helps } \\
\text { move a person from one point } \\
\text { to another. } \\
\text { Perception: Coaching should } \\
\text { move someone from where } \\
\text { they are to where they are } \\
\text { intended to be. } \\
\text { Experience - Will and Skill } \\
\text { Experience: Coaching improves } \\
\text { skills } \\
\text { Experience: Coaching cannot } \\
\text { help if there is no will. } \\
\text { Experience: It is important to } \\
\text { know the purpose of coaching. } \\
\text { Experience: Coaching can be for } \\
\text { performance related issues } \\
\text { Experience: coaching can be for } \\
\text { attitudinal/behavioural issues } \\
\text {. }\end{array}$ \\
\hline
\end{tabular}




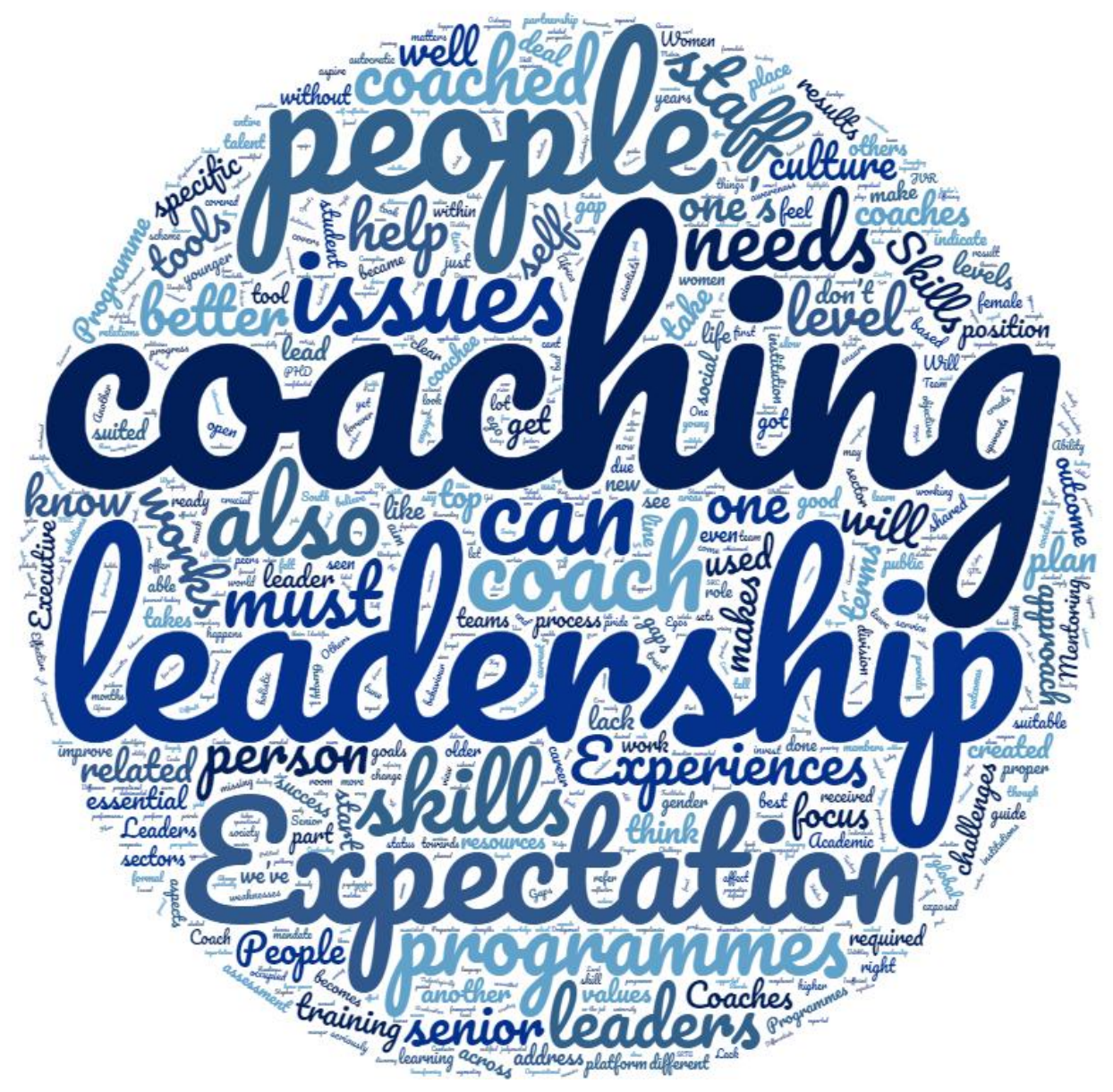

Figure 4: Wordlandscapes presentation of actual codes

After transposing codes and enlisting them, researchers then examine data for frequencies and similarities. That action automatically shifts the process to the axial coding stage (Saldana, 2016 ; Charmaz, 2008). The second stage of coding affords the coders an opportunity to try and urstand code "behaviors", similarities and patterns. This automatically calls for search of meanings and themes through continued immersion in data (Nowell, et al., 2017). The process on its own further enhances data authenticity as sub- themes are generated directly from transformed data. Figure 4 below demonstrates how the subthemes and final themes are generated. The method further provides for consistency and replicability. 


\section{ACHHOR CODE 1 - LEADERSHIP DEVELOPMENT}

My company develops leaders and managers (56)

There is no formal leadership development programme (47)

Coaching programme implemented and

formalised in the organisation (40)

Need for focussed leadership at senior

level (23)

Succession planning in place (6)

Coaching programme implemented but

not formalised (4)

Qualified incumbents on leadership/senior management positions (4)

Academic development alone does not

address work-related issues (2).

We are not doing well in public service (5)

Coaching should be customised to African

perspectives of leadership (1)

Coaching should be embraced at national

level (1)

Coaching was not embraced in the

organisation (1)

All sectors of society provide a leadership development platform (1)

\section{THEME ONE}

\section{ACHHOR CODE 2 - EFFECTIVENESS}

THEME TWO

Coaching is effective (11)

Coaching provides clarity and self

understanding (4)

Application of behaviour assessment tools (9)

Professional coaching should not cover

personal life (2)

Can be implemented to ministers and their deputies (1)

Coaching also helps with managing personal

rolatinnchinc 11

intervention in

South African

organisations
A well planned executive coaching supports continuous personal

improvement for leaders and managers.

\section{ACHHOR CODE 3 - EXPECTATION}

Continuous improvement (22)

A coaching relationship that is safe, respectful, trusting and confidential (21)

Help in reflective self discovery (9)

Coach needs to have the art and skill, with ultimate goal to create better performers (7)

Good relationship between coach and coachee (3)

Should start with needs analysis (2) (see effectiveness)

Figure 5: Deductive and Inductive Codes 
- Flat-Listed Coding Structure: whereby the coder has single inductive codes not linked to deductive codes as demonstrated in Figure 5 below. This is helpful in a needs analysis type of a study - most popular in business research.

In this method, the researcher simply creates inductive codes from data documents and later on observes the behavior of these codes in terms of frequencies and relations so as to generate themes, using the same process as mentioned above.

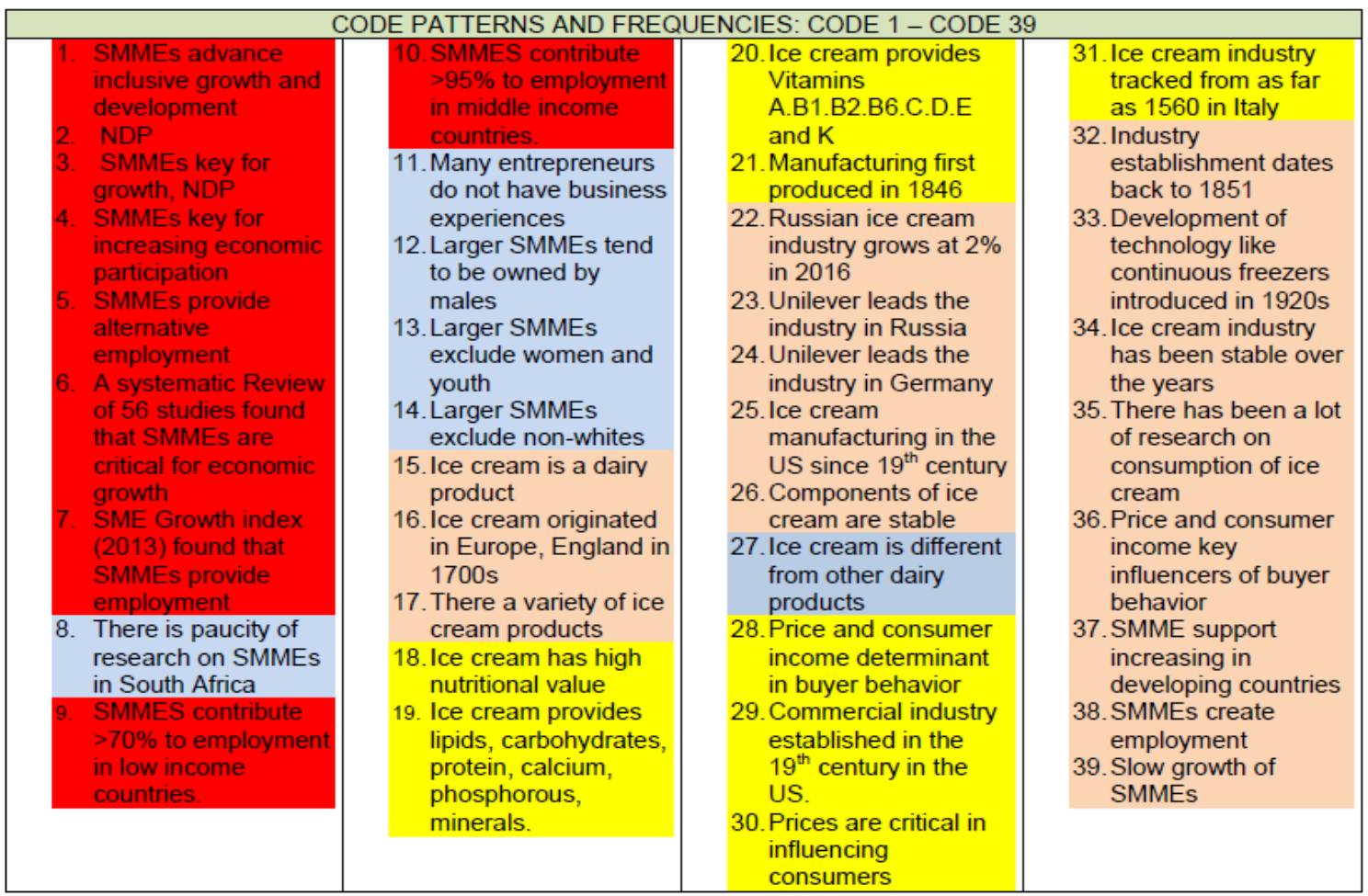

Figure 6: Flat-listed codes

Tables 1 and 2 below are a true reflection of a study entitled "Systematic review of opportunities within the ice-cream industry in Limpopo Provice." This method was used in completion of an MBA thesis submited in 2020. Codes were also followed by a presentation of wordclouds and, categorisation and final themes emanating from data. 

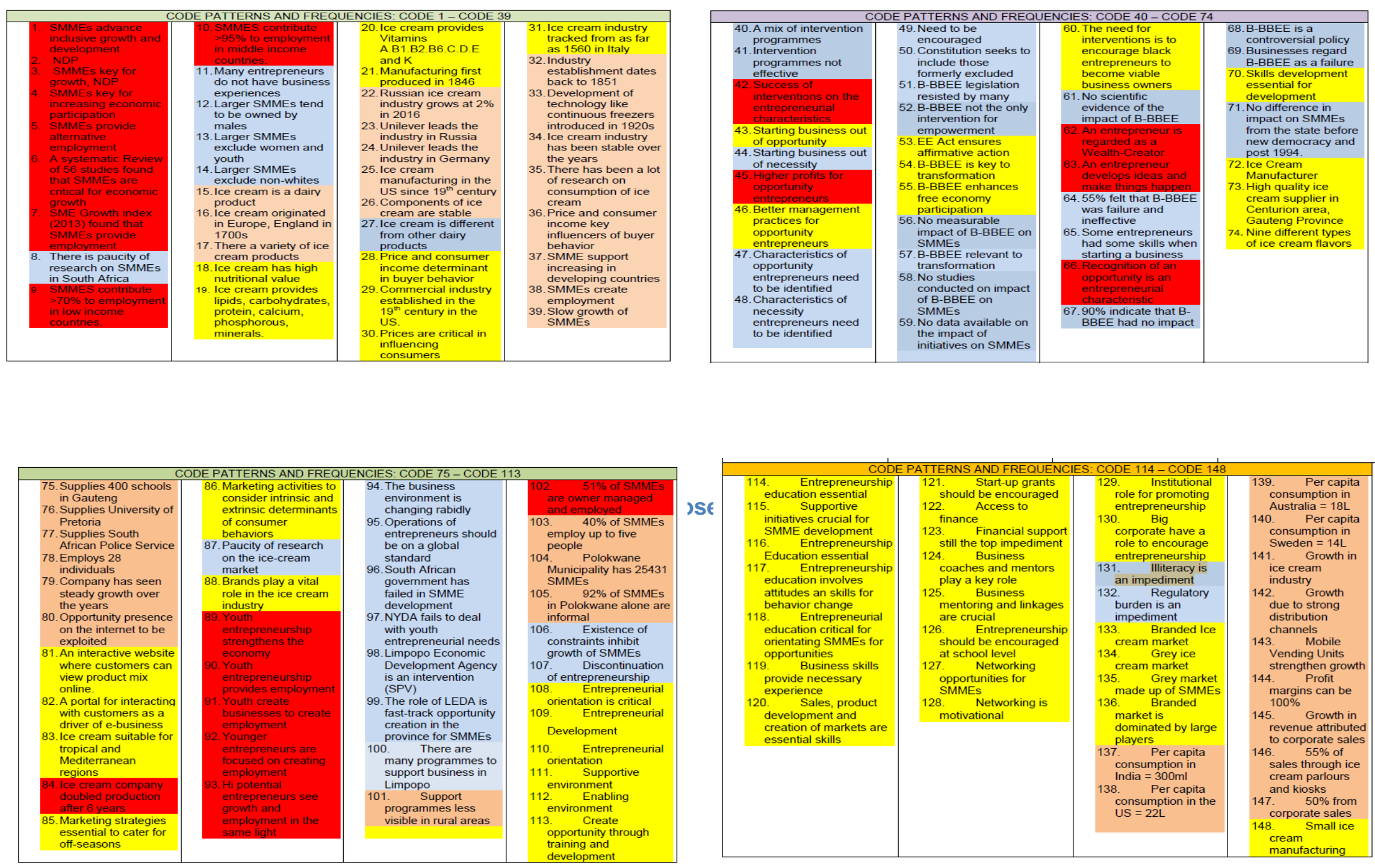

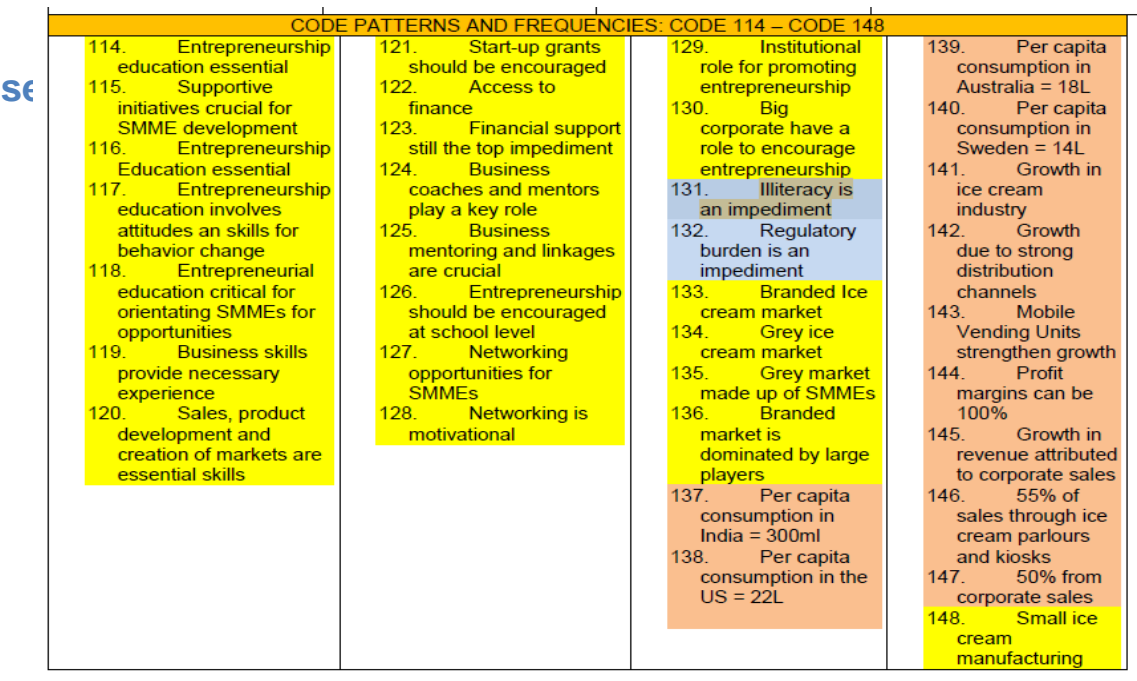




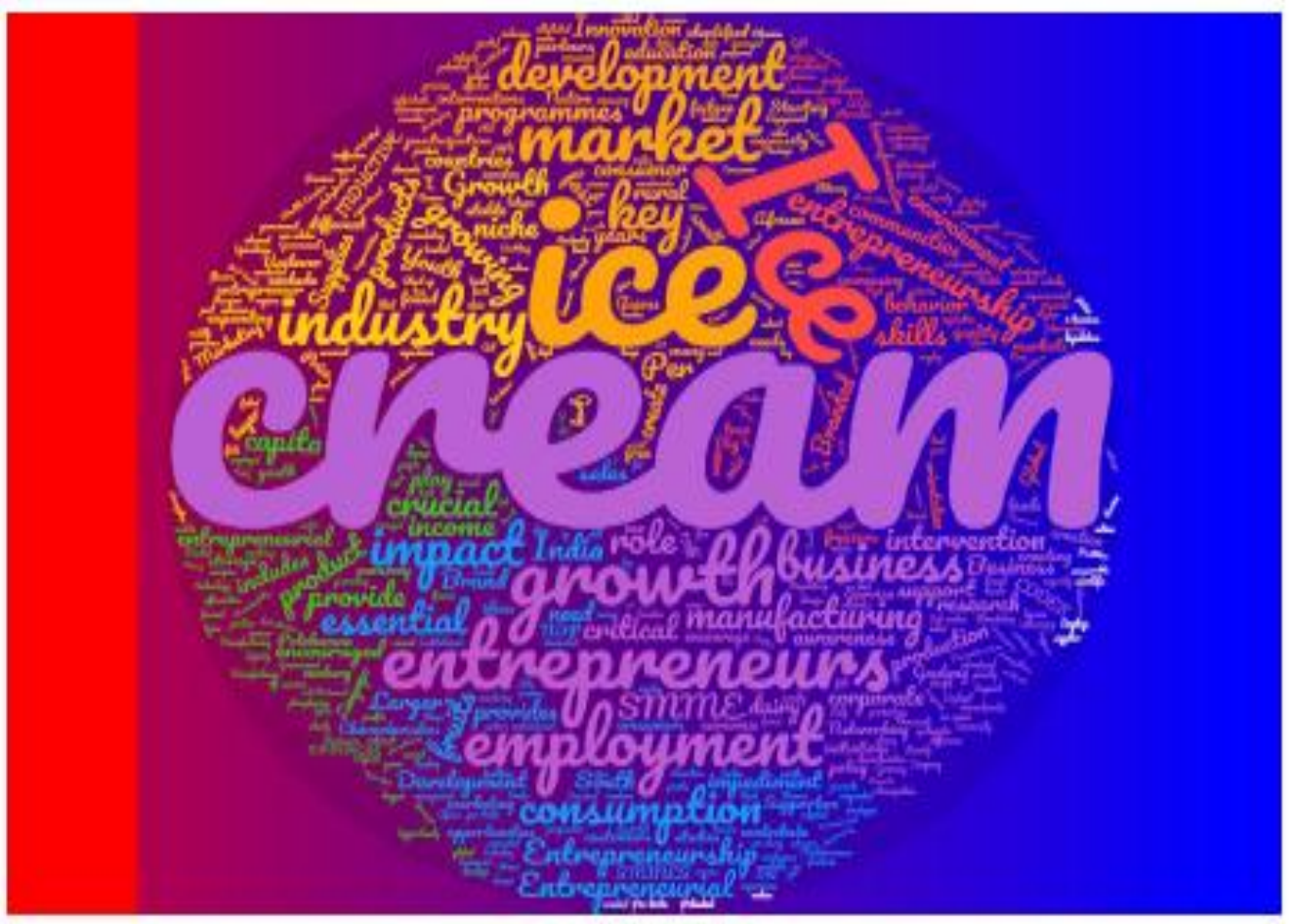

Figure 7: Wordclouds of Flatlisted Codes in an MBA study, 2020

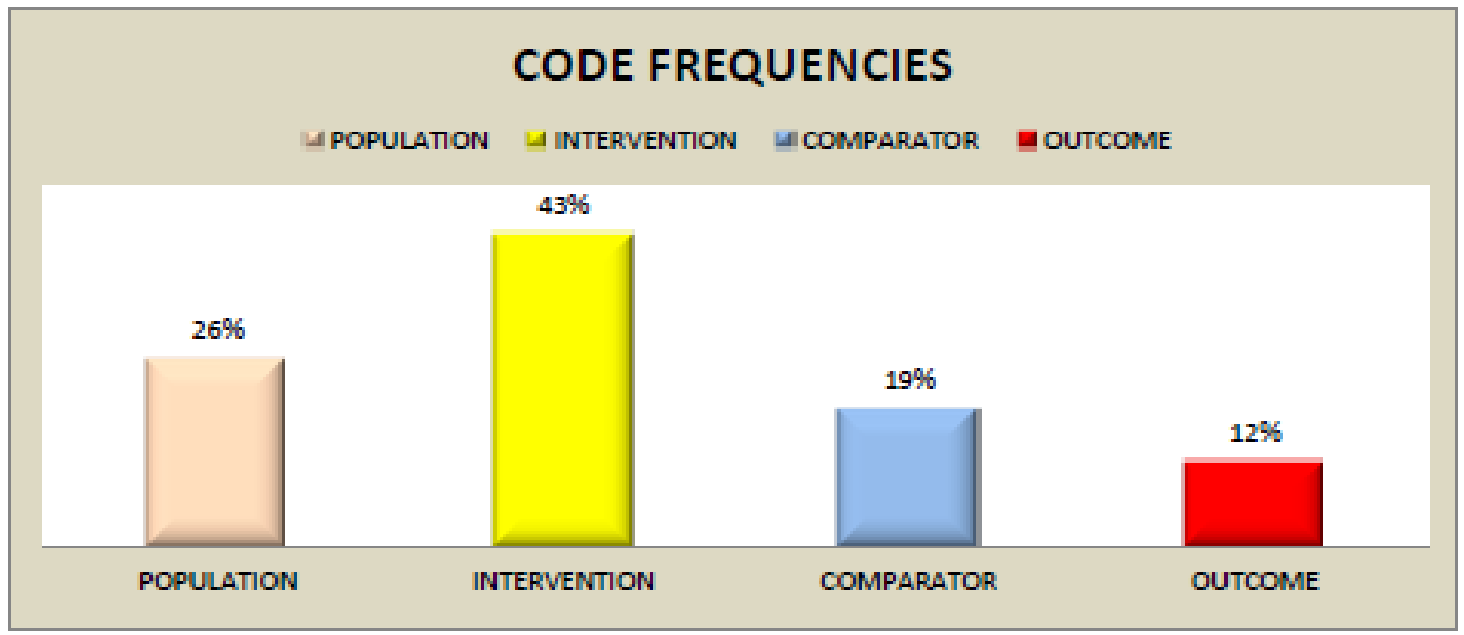

Figure 8: Code frequencies in the MBA study, 2020 


\section{CONCLUSIONS}

The author hereby proposes that clear demarcations and distinctions in the use of textual analysis methods need to be taught and understood. Whereas many scholars indicated that the use of thematic analysis appears across many publications from different contexts, application seems to be even more confused within different methods of qualitative data analysis. Whilst the concept origination and placement of thematic analysis can be traced both from Content Analysis during the world wars, as postulated in Costa and Amado (2018), the use of codes and themes was improved later on in Grounded Theory (Glaser \& Strauss, 1967; Charmaz, 2008). The methods used in the work of Charmaz clearly demonstrate step by step methods of initial coding, which could be useful to students and largely used as an approach in the Costa QDA.

Whilst quantitative researchers apply statistical methods for establishing the validity and reliability of research findings, qualitative researchers aim to design and incorporate methodological strategies to ensure the 'trustworthiness' of the findings. These strategies are summarized as follows:

- Consideration is given for personal biases which may have influenced the findings

- Consideration of biases in sampling and ongoing critical reflection of methods to ensure sufficient depth and relevance of data collection and analysis

- Meticulous record keeping, demonstrating a clear decision trail and ensuring interpretations of data are consistent and transparent

- Establishing a comparison case/ seeking out similarities and differences across accounts to ensure different perspectives are represented

- Including rich and thick verbatim descriptions of participants' accounts to support findings

- Demonstrating clarity in terms of thought processes during data analysis and subsequent interpretations

- $\quad$ Engaging with other researchers to reduce research bias

- Respondent validation: includes inviting participants to comment on the interview transcript and whether the final themes and concepts created adequately reflect the phenomena being investigated 
- $\quad$ Data triangulation, whereby different methods and perspectives help produce a more comprehensive set of findings

This guide/article sought to present the simplified method of Qualitative Data Analysis as espoused in the C.O.S.T.A. Postgraduate Research Coaching Model. It is a framework analysis anchored primarily on the work of Costa and Amado (2018); Braun and Clarke (2006); Dey, (1993). This method has been preferred and accepted in most of the research projects wherein the students were coached by the author. The latest success of the method acceptance was in the study of (Mvelase, 2019); and other students within the Global Centre for Academic Research programme.

The task of performing thematic analysis can be massively daunting and laborious. We therefore recommend that researchers employ the use of best software to enhance, procedural consistency, data accuracy and management throughout the analysis process, while bearing in mind that data analysis software programmes do not actually perform the analysis, but enhance the practice, as concluded by Zamawe (2015). To aid teaching of thematic analysis, the researcher recommends the use of webQDA programme, due to the fact that its applicability to different contexts that support collaboration has been assessed (Silver, 2018) and further integrated into the Costa QDA method.

\section{COSTA QDA ON WEbQDA SOFTWARE}

This section introduces the webQDA software, a cloud based programme is aimed at data analysts, researchers and scholars in different contexts and settings within the qualitative research environment. This software enables analysts to perform their data analysis projects individually or in teams. The ability of performing projects in teams enhances the rigor requirement of peer debriefing, which enhances the dimension of credibility (Forero, et al., 2018). In terms of comparison with popular CAQDAS applications in the market, WebQDA follows popular structural and theoretical designs, although the key differentiator is its simplicity of functionality and adaptation to different types of research. Costa and Amado (2018) have listed the main features of webQDA as follows:

- Web-based software

- Handling of text, image, video and audio sources

- Collaborative and distributed environment (through the web)

- Simple and intuitive use 
- Suitable for different strategies and research methods

- Compatible with all operating systems

- Total security of data

As part of the value proposition, the author suggests the use of WebQDA as it is cloud-based, meaning that accessibility is not geographically restricted between research team members. In the academic context, webQDA is especially useful for researchers, masters, doctoral students and postgraduates who develop qualitative data analysis. In the business context, webQDA has application in the analysis of data coming from the market, such as, for example, type of consumers.

With webQDA, the researcher can edit, view, link and organize documents. At the same time, one can create categories, code, control, filter, search, and query data to answer the questions that emerge from research.

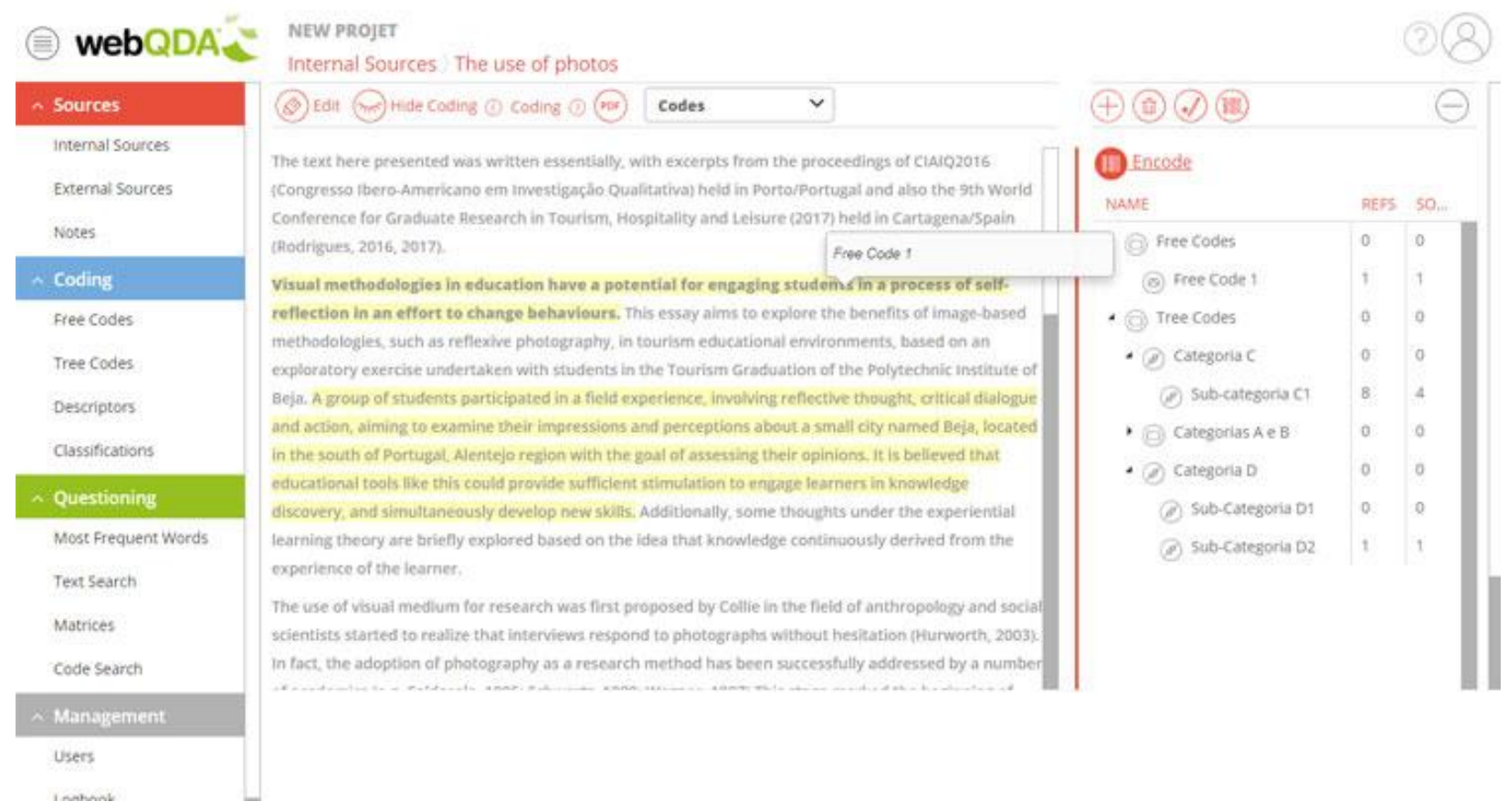

Figure 9: COSTA QDA with webQDA Software 


\section{REFERENCES}

Academy of Science of South Africa, 2010. The PHD Study: An Evidence-based study on how to meet the Demands for high-level Skills in an emerging Economy, Pretoria: Academy of Science of South Africa.

Academy of Science of South Africa, 2010. The PHD Study: An Evidence-based study on how to meet the Demands for high-level Skills in an emerging Economy, Pretoria: Academy of Science of South Africa.

Adams, J., Hillier-Brown, F., Moore, H. \& al., e., 2016. Searching and synthesising 'grey literature'and 'grey information' in public health: critical reflections on three case studies. Syst Rev, Volume 5, pp. https://doi.org/10.1186/s13643-016-0337-y.

Ahuvia, A., 2001. Traditional, interpretive, and reception based content analyses: Improving the ability of content analysis to address issues of pragmatic and theoretical concern. Social Indicators Research, Volume 54, p. 139-172.

Bahrami, N., Soleimani, M., Yaghoobzadeh, A. \& Ranjbar, H., 2016. Researcher as an Instrument in Qualitative Research: Challenges and Opportunities. Advances in Nursing and Midwifery, Volume 25, pp. 27-37.https://doi.org/10.22037/anm.v25i90.11584.

Baptiste, I., 2001. Qualitative data analysis: common phases, strategic differences. Forum Qualitative Sozialforschung/Forum: Qualitative Social Research [On-line Journal]., 2(3).

Bettany-Saltikov, J., 2012. How to do a systematic review in nursing. Berkshire: Open University Pres.

Bettany-Saltikov, J., 2012. How to do a systematic review i nnursing. Berkshire: Open University Press.

Bingo, S., 2018. Living with cancer of the head and neck: a qualitative inquiry into the experiences of patients treated at an academic hospital in Gauteng, Johannesburg: University of the Witwatersrand.

Bloor, M. \& Wood, F., 2006. Keywords in Qualitative Methods:AVocabulary of Research Concepts. 1 ed. London: SAGE Publications.

Boyatzis, R., 1998. Transforming qualitative information: Thematic analysis and code development. Thousand Oaks, CA: SAGE Publications.

Boyatzis, R., 1998. Transforming qualitative information: Thematic analysis and code development.. Thousand Oaks, CA: SAGE Publications..

Boyatzis, R. E., 1998. Transforming qualitative information: Thematic analysis and code development. Thousand Oaks: Sage. 
Brakenhoff, B., 2012. A Thematic Analysis of Substance-Abusing Mothers' and Their Children's Discussions during Family Therapy, s.I.: The Ohio State University.

Braun, V. \& Clarke, V., 2006. Using thematic analysis in psychology. Qualitative Research in Psychology,, Volume 3, p. 77-101.

Brierley, J., 2017. The role of a pragmatist paradigm when adopting mixed methods in behavioral accounting research. International Journal of Behavioural Accounting and Finance, pp. 140-154.

Burmeister, E. \& Aitken, L. M., 2012. Sample size: How many is enough?.. Australian Critical Care, pp. 271-274, doi: 10.1016/j.aucc.2012.07.002 .

Carmichael, T. \& Cunningham, N., 2017. Theoretical Data Collection and Data Analysis with Gerunds in a Constructivist Grounded Theory Study., Johannesburg: Wits Business School.

Castleberry, A. \& Nolen, A., 2018. Thematic analysis of qualitative research data: Is it as easy as it sounds?. Currents in Pharmacy Teaching and Learning, 10(6), pp. 807-815. https://www.sciencedirect.com/science/article/abs/pii/S1877129717300606.

Cekiso, M., Tshotsho, B., Masha, R. \& Saziwa, T., 2019. Supervision experiences of postgraduate research at one South African higher education institution. South African Journal of Higher Education, 33(3), pp. 8-25.https://doi.org/10.20853/33-3-2913.

Chambers, A., 2014. Expecting the Unexpected: How Novice Researchers Negotiate Unexpected Ethical Issues, Dunedin: University of Otago.

Chandrakantha, L., 2014. Excel Simulation as a Tool in Teaching Sampling Distributions in Introductory Statistics, New York: John Hay College of Criminal Justice of CUNY..

Charmaz, K., 2008. Constructionism and Grounded Theory. In: J. Holstein \& J. Gubrium, eds. Handbook of Constructionist Research. New York: The Guilfordpress, pp. 397-412.

Charmaz, K., 2008. Grounded Theory as an Emergent Method. In: S. Hesse-Biber \& P. Leavy, eds. Handbook of Emergent Methods. New York: The Guilford Press, pp. 155-172.

Clarke, V. \& Braun, V., 2006. Using thematic analysis in psychology. Qualitative Research in Psychology, Volume 3, p. 77-101. doi:10.1191/1478088706qp063oa.

Clarke, V. \& Braun, V., 2013. Teaching thematic analysis: Overcoming challenges and developing strategies for effective learning. British Psychological Society, 26(2), pp. 120-123.

Clarke, V., Braun, V. \& Hayfield, N., 2015. Thematic analysis. In: J.A.Smith, ed. Qualitative Psychology: A Practical Guide to Research Methods. London: Sage.

Clur, L., 2015. Returning to work: exploring the lived experience of the cancer survivor, Pretoria: University of South Africa. 
Cohen, L., Manion, L. \& Morrison, K., 2005. Research Methods in Eduation. London: RoutledgeFalmer.

Collins, R., 1984. Statistics versus words. Sociological Theory, Volume 2, pp. 329-362.

Colorado State University, 2012. Colorado State University's open-access learning environment, the Writing Studio.. [Online]

[Accessed 1009 2019].

Costa, K., 2018. A systematic review of challenges in research supervision at South African. Preprints, pp. 33-39.

Costa, K., 2018. A Systematic Review of Challenges in Research Supervision at South African Universities. Preprints, pp. 33-39.

Costa, K., 2019. Introducing the C.O.S.T.A. Postgraduate Research Coaching Model-A Complementary Approach to Supervision. Preprints.

Costa, K., 2019. Systematic Guide to Qualitative Data Analysis Within the C.O.S.T.A Postgraduate Research Model. OSF Preprints, p. doi:10.31219/osf.io/sq2dh..

Costak, K., 2019. INTRODUCING THE C.O.S.T.A. POSTGRADUATE RESEARCH COACHING MODEL - A COMPLEMENTARY APPROACH TO SUPERVISION. Porto, Portugal, World Conference on Qualitative Research.

Costa, P. \& Amado, J., 2018. Content Analysis Supported by Software. Aveiro: Ludomedia.

Costa, P. \& Amado, J., 2018. Content Analysis Supported by Software. Aveiro: Ludomedia.

Creswell, J. W., 2009. Research design: Qualitative, quantitative, and mixed methods approahed. 3 ed. Thousand Oaks: SAGE.

Denzin, N. K. \& Lincoln, Y., 2000. Handbook of Qualitative Research. 2 ed. Thousand Oaks: Sage.

Dey, I., 1993. Qualitative Data Analysis: A User-friendly Guide for Social Scientists. New York: Routledge.

Dibley, L., 2011. Analyzing narrative data using McCormack's lenses. Nurse Researcher, pp. 13-19.

EPPI-Centre, 2006. Descriptive Mapping, London: Institute of Education.

Felix, E., 2019. Contextual intelligence behaviours: managers in multinational enteprises developing emerging markets, Pretoria: Gordon Institute of Business Science, University of Pretoria. 
Forero, R., Nahidi, S. \& De Costa, J. e. a., 2018. Application of four-dimension criteria to assess rigour of qualitative research in emergency medicine. BMC Health Serv Res , 18(20), pp. https://doi.org/10.1186/s12913-018-2915-2.

Francis, K., 2019. An exploratory study into the critical success factors for effective stakeholder engagement in blended finance projects, Pretoria: Gordon Institute of Business Science University of Pretoria.

Frankel, R. \& Devers, K., 2000. Study design in qualitative research-1: developing research questions and assessing research needs.. Education for Health, Volume 13, p. 251-261.

Frassinelli, P., 2018. You can look it up : research and the internet. In: Msking sense of research. Pretoria: Van Schaik Publishers.

Frescura, F., 2018. Towns and gowns and bawdy songs too : the symbology of academia. In: Making sense of research. Pretoria: Van Schaik Publishers, pp. 11-18.

Glaser, B. \& Strauss, A., 1967. The discovery of grounded theory: strategies for qualitative research. Chicago: Aldine.

Grant, M. \& Booth, A., 2009. A typology of reviews: an analysis of 14 review types and associated methodologies. Health Information and Libraries Journa, Volume 26, pp. 91-108. DOI: 10.1111/j.1471-1842.2009.00848.

Greene, J. \& Caracelli, V., 2003. 'Making paradigmatic sense of mixed-method practice'. In: Handbook of Mixed Methods in Social and Behavioral Research. Thousand Oaks CA: Sage.

Guba, E. G. \& Lincoln.Y, S., 1985. Naturalistic Inquiry. Beverly Hills: Sage.

Guest, G., Bunce, A. \& Johnson, L., 2006. How many interviews are enough? An experiment with data saturation and variability. Field Methods, 18(1), p. 59-82.

Henn, M., Weistein, M. \& Foard, N., 2009. A Critical Introduction to Social Research. 2 ed. London: Sage.

Holloway, I. \& Todres, L., 2003. The status of method: Flexibility,consistency and coherence.. Qualitative research, Volume 3, p. 45-357 : doi:10.1177/1468794103033004.

Hsieh, H. \& Shannon, S. E., 2005. Three approaches to qualitative content analysis.. Qualitative health research, 15(9), pp. 1277-1288.

Janesick, V., 2001. Intuition and creativity: a pas de deux for qualitative researchers. Qualitative Inquiry, 7(5), p. 531-540.

Javadi, M. \& Zarea, K., 2016. Understanding Thematic Analysis and its. Journal of Client Care, 1(1), pp. 33-39. doi: 10.15412/J.JCC.02010107.

Joffe, H. \& Yardley, L., 2004. Content and thematic analysis. . In: In D. F. Marks \& L. Yardley (Eds.), Research methods for clinical and health psychology . London: Sage, p. 56-68. 
Jugder, N., 2016. The thematic analysis of interview data: an approach used to examine the influence of the market on curricular provision in Mongolian higher education institutions, s.l.: University of Leeds.

King, N., 2004. Using templates in the thematic analysis of text. In: C. Cassell \& G. Symon, eds. Essential guide to qualitative methods in organizational research. London, UK: SAGE Publications, p. 257-270.

Kljakovic, M., 2009. Developing a teaching research culture for general practice registrars in Australia: a literature review. Asia Pacific Family Medicine, 8(6), pp. doi:10.1186/1447-056X-86.

Krippendorff, K., 1980. Content Analysis: An Introduction to Its Methodology. Newbury Park, CA: Sage Publishers.

Loh, J., 2013. Inquiry into Issues of Trustworthiness and Quality in Narrative Studies: A Perspective. The Qualitative Report, 18(33), pp. 1-15. Retrieved from https://nsuworks.nova.edu/tgr/vol18/iss33/1.

Maguire, M. \& Delahunt, B., 2017. Doing a Thematic Analysis: A Practical, Step-by-Step Guide for Learning and Teaching Scholars. AISHE-J, Volume 3.

Maguire, M. \& Delahunt, D., 2017. Doing a Thematic Analysis: A Practical, Step-by-Step Guide for Learning and Teaching Scholars. All Ireland journal of Teaching and Learning in Higher Education, Volume 3.

Makuwa, M., 2014. Exploring experiences of adolescents living with a depressed parent, Pretoria: University of South Africa.

Mallozzi, C., 2009. Voicing the interview: a researcher's exploration on a platform of empathy. Qualitative Inquiry, 15(6), p. 1042-1060.

Malterud, K., 2001. Qualitative research: Standards, challenges, and guidelines. The Lancet, Volume 358, pp. 483-488. doi:10.1016/S0140-6736(01)05627-6.

Malterud, K., Siersma, V. \& Guassora, A., 2015. Sample size in qualitative interview studies: guided by information power. Qual Health Res, Volume 26, p. 1753-60.

Massachusetts Institute of Technology, 2020. Database Search Tips: Boolean operators. [Online] Available at:

https://libguides.mit.edu/c.php?g=175963\&p=1158594\%20[Accessed\%2008\%2003\%202020]. [Accessed 1507 2020].

Matteson, S. \& Lincoln, Y., 2009. Using multiple interviewers in qualitative research studies: the influence of ethic of care behaviors in research interview settings. Qualitative Inquiry, 15(8), p. 659-674. 
Mdyogolo, W., 2012. The academic experiences of faculty of education postgraduate students who have dropped out of a higher education institution in Eastern Cape Province, s.I.: University of Fort Hare..

Miles, M. B. \& Huberman, A. M., 1994. Qualitative Data Analysis - An Expanded Sourcebook. Thousand Oaks: Sage Publications.

Mlokothi, M., 2017. Leadership development for women at the department of home affairs, Johannesburg: University of the Witwatersrand.

Moodley, S., 2019. The Lived Experience: A qualitative study of mentally ill women who commit filicide, Johannesburg: University of the Witwatersrand.

Mthembu, A., 2017. Challenges and opportunities experienced by people with a physical disability in Alexandra, Gauteng, Johannesburg: University of the Witwatersrand.

Mukuvisi, D., 2011. Challenges and Opportunities of a Donor-Funded Not-for-Profit Organisation: a SWOT Analysis of Vikela Project, a Business Unit of Composite Health, Durban: Management College of Southern Africa (MANCOSA).

Mvelase, M., 2019. The perceived effectiveness of executive coaching for leadership development in South Africa, Johannesburg: University of the Witswatersrand.

Mvelase, M., 2019. The perceived effectiveness of executive coaching for leadership development in South Africa, Johannesburg: s.n.

Neuendorf, K. A., 2017. The content analysis guidebook. 2 ed. Thousand Oaks:CA: Sage.

Neuman, W. L., 2006. Social Research Methods: Qualitative and Quantitative Approaches. London: Pearson Education, Inc.

Nowell, L. S., Norris, J. M., White, D. E. \& Moules, N. J., 2017. Thematic Analysis: Striving to Meet the Trustworthiness Criteria. International Journal of Qualitative Methods, p. https://doi.org/10.1177/1609406917733847.

Nowell, L. S., Norris, J. M., White, D. E. \& Moules, N. J., 2017. Thematic Analysis: Striving to Meet the Trustworthiness Criteria.. International Journal of Qualitative Methods, 16(1), pp. 1-13.

Nowell, S. L., Noris, M., White, E. \& Moules, J., 2017. Thematic Analysis: Striving to Meet Trustworthiness Criteria. International Journal of Qualitative Methods, Volume 16, pp. 1-13.

O'Gorman, K. \& MacIntosh, R., 2015. Research Methods for Business \& Management. 2 ed. Oxford: Goodfellow Publishers Ltd.

O'Reilly, M. \& Parker, N., 2012. 'Unsatisfactory Saturation': a critical exploration of the notion of saturated sample sizes in qualitative research. Qualitative Research, pp. 190-197, DOI:

$10.1177 / 1468794112446106$. 
Padilla-Díaz, M., 2015. Phenomenology in Educational Qualitative Research: Philosophy as Science or Philosophical Science?. International Journal of Educational Excellence, 1(2), pp. 101-110.

Padilla-Díaz, M., 2015. Phenomenology in Educational QualitativeResearch: Philosophy as Science or Philosophical Science?. International Journal of Educational Excellence.

Papakyriakou, X., 2014. Professional Black South African Women: Body Image, Cultural Expectations and the Workplace, Pretoria: University of South Africa.

Pezalla, A., Pettigrew, J. \& Miller-Day, M., 2012. Researching the researcher-as-instrument: an exercise in interviewer self-reflexivity.. Qual Res, 12(2), p. 165-185.

doi:10.1177/1487941111422107..

Polit, D. \& Beck, C., 2012. Nursing research.. Philadelphia: Wolters Kluwer Health/Lippincott Williams \& Wilkins..

Reid, M., 2012. The impact of group coaching on leadership effectiveness for South African women managers, Johannesburg: University of the Witwatersrand.

Ryan, G. \& Bernard, H., 2000. Data management and analysis methods. In: N. Denzin \& Y. Lincoln, eds. Handbook of qualitative research. Thousand Oaks : CA: SAGE Publications, p. 769-802.

Saldana, J., 2016. The Coding Manual for Qualitative Researchers. 3 ed. London: Sage.

Sandelowski, M., 1995. Qualitative analysis: What it is and how to begin. Research in Nursing and Health, 18(doi:10.1002/nur.4770180411), p. 371-375.

Sandelowski, M., 2004. Using qualitative Research. Qualitative Health Research, Volume 14, p. 1366-1386. doi:10.1177/1049732304269672.

Schatzman, L. \& Straus, A., 1973. Field Research:Strategies for a natural sociology. Englewood Cliffs: Prentice- Hall.

Sethuntsha, M., 2017. The Development of a Therapeutic Approach for the Treatment of Individuals with Prader-Willi Syndrome and their Primary Caregivers, Pretoria: University of South Africa.

Silver, C., 2018. Software Reviews: webQDA. [Online]

Available at: https://www.surrey.ac.uk/sites/default/files/2018-09/webgda-review-august-

2018.pdf

[Accessed 1707 2020].

Smith.A.F., 2018. Perceived Influence of Inequality on the Career Development of Emerging Adults In South Africa, Pretoria: University of South Africa.

Southwel, G., 2013. How has surrender been written about in psychoanalytic psychotherapy, s.I.: Auckland University of Technology. 
Starks, H. \& Trinidad, S. B., 2007. Choose your method: A comparison of phenomenology, discourse analysis, and grounded theory. Qualitative Health Research, Volume 17, p. 13721380. doi:10.1177/1049732307307031.

Stemler, S., 2001. An Overview of Content Analysis. Practical Assessment, research \& Evaluation, 7(17).

Sylvester, C., 2016. A qualitative action research study introducing a metacognitive framework for teaching preparation and analysis of its efficacy, Johannesburg: University of the Witswatersrand.

Terry, G., Hayfield, N., Clarke, V. \& Braun, V., 2017. Thematic Analysis. In: C. Willing \& W. Stainton-Rogers, eds. The Sage Handbook of Qualitative Research in Psychology. London: Sage, pp. 17-37.

Thorne, S., 2000. Data analysis in qualitative research. Evid. Based Nurs, p. doi:10.1136/ebn.3.3.68 .

Thorne, S., 2000. Data analysis in qualitative research. Evidence Based Nursing, Volume 3, p. 68-70.doi:10.1136/ebn.3.3.68.

Tuckett, A., 2005 . Applying thematic analysis theory to practice: A researcher's experience. Contemporary Nurse, Volume 19, p. 75-87.

Vaismoradi, M., Jones, J., Turunen, H. \& Snelgrove, S., 2016. Theme development in qualitative content analysis and thematic analysis. Journal of Nursing Education and Practice, $6(5)$.

Wanberg, C. R., Welsh, L. \& Hezlett, S., 2003. Mentoring: A review and directions for future research. In J. Martocchio \& J. Ferris (Eds.). Oxford: Elsevier Science Ltd.

Zamawe, F., 2015. The Implication of Using NVivo Software in Qualitative Data Analysis: Evidence-Based Reflections. Malawi Medical Journal, 27(1), p. 13-15. 
